\title{
M-Learning In Higher Education: Exploring The Gender Based Faculty Performance Of Business Schools In Pakistan
}

\author{
Salman Manzoor \\ Department of Commerce \\ University of Karachi \\ Samiullah Sarwar \\ Department of Education \\ University of Loralai \\ Muhammad Asim \\ Karachi University Business School \\ University of Karachi
}

\begin{abstract}
This study aims to observe the influence of inclusion of mobile learning in Business Schools on students' performance and gender based faculty members' performance in business schools in Karachi, Pakistan. The functions offered in mobile phones include the access to information of real-time, medium of communication, and host of affordances. Nevertheless, along with the opportunities and incentives the mobile devices carry opportunities for students to involve in academic dishonesty, deviation and distraction from the assigned tasks. By employing quantitative research method, this study tends to conduct an experiment to explore if faculty members in business schools perform differently based on their different genders with the inclusion of mobile learning. The result of the study reveals no difference between the performance of male and female faculty members with the inclusion of mobile learning by implementing the Google Class into their regular classes. Therefore, this study recommends the academic leaders, curriculum designers, and educationists in the field of business education to pay attention on the inclusion of mobile learning, as it is equally beneficial to students and faculty members regardless of their different genders.
\end{abstract}

Keywords: Gender Difference, Faculty Performance, Mobile Learning, Higher Education, Business Education.

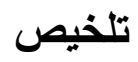

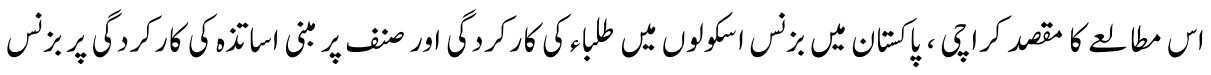

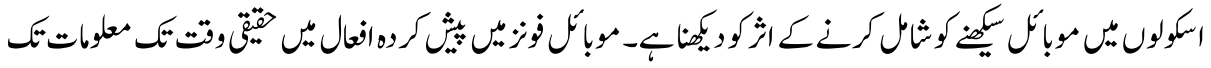

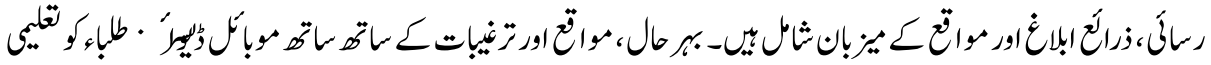

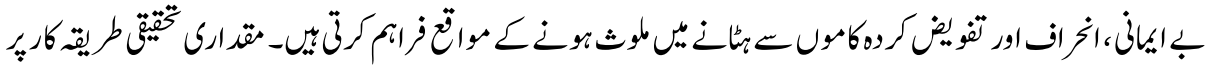

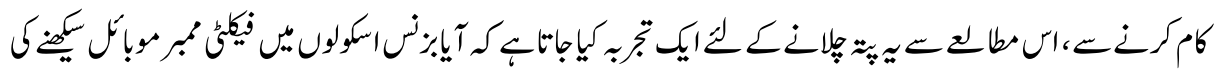




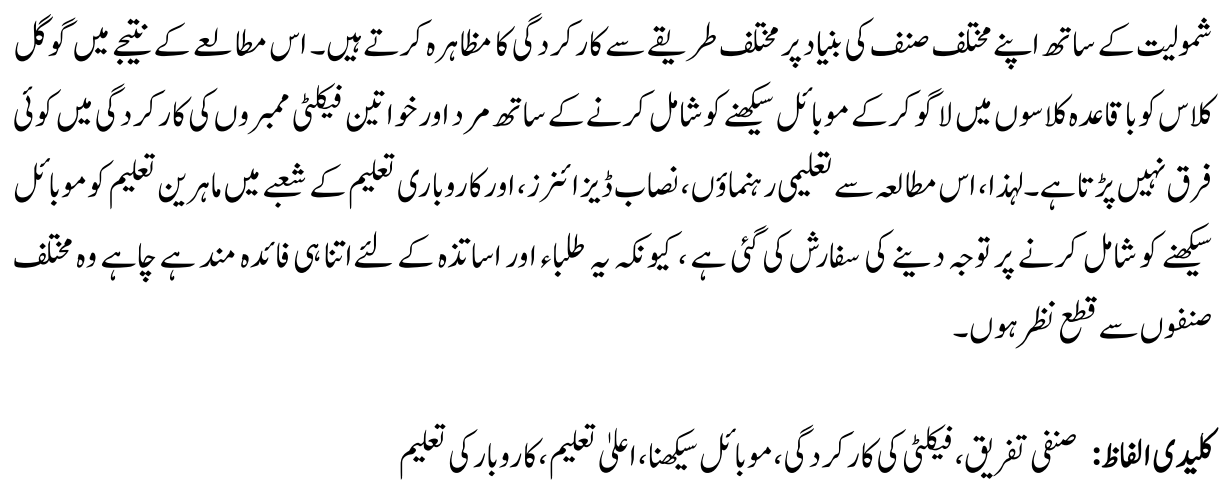

\section{Introduction}

With the increased use of technology worldwide, the attached efficiencies with the technological instruments have drawn attention of decision makers in various fields of life. According to Allen (2011), the increased use of technology is the result of globalization, which has increased the notion of competition significantly in various fields of life. Consequently, nations are now in the need to grow in the field of technology to optimize the performance. Keeping the efficiencies associated with the use of technology, Allen (2011) figures out that mobile learning (also named as m-learning) is an emerging concept which has proved its significance in the field of educational industry in terms of assisting learners to increase their academic performance. Beal (2018) argues that the term "mobile learning," used in the context of education, refers to the learning that takes place with the assistance mobile phones or other mobile like devices such as tabs, tablets, and personal digital assistant (PDA).

Clark \& Ed (2007) argue that"Mobile learning, or learning accomplished with the use of small, portable devices (Mobile Learning), is not one of the new educational paradigms that suddenly blossom in the field of education, become wildly popular for a few years, then quietly fade away. It is simply a new vehicle for delivering education to today's learners via mobile phones, PDAs, tablet PCs, etc." (p. 1). Today, learners want to possess the ability to learn with convenience of place to be present. Mobile learning seems to be a perfect delivery vehicle for today's learners. The shift of mobile services from the electronic services has brought new paradigm known as "anytime, anywhere computing" which has taken the new generation towards the electronic learning (Lehner, Nosekabel, \& Lehmann, 2003). Considering this perspective, Lehner, Nosekabel, and Lehmann (2003) call the mobile learning as a way that can be used to keep people connected and learning from anywhere and anytime by carrying the handheld devices such as mobile or other mobile like devices.

From this perspective, the purpose for the inclusion of mobile learning in the Higher Education is to meet the needs of learners where mobile learning facilitate the learners regarding learning time, time flexibility, assimilated instructional context, collaborative 
sessions to acquire knowledge, and situational instructional activities (Nassuora, 2012).Mobile devices usually contain features and applications designed for learners to enhance their learning. According to Laouris \& Eteokleous (2005), learners can extend their learning, with the assistance of m-learning, via social interaction as well as other conceivable mean and thus do not require a precise cite to mark their presence. Furthermore, learners can have quick access to the resources to increase their information, which is a significant source to increase the motivational level of the learners (Ally \& Prieto-Blázquez, 2014). In the present day, students and teachers use mobile phone increasingly for the educational purpose, which has urged the researchers to pay attention on the notion of integrating m-learning in educational curriculum to improve their academic performance as well as to improve the students' interaction with their teachers. The developed theories (Information System Success Model (ISSM), Motivational Model (MM), Social Cognitive Theory (SCT), Technology Acceptance Model (TAM), and Cultural Dimension Theory (CDT) regarding the adoption intentions (increased use of technology) are the significant contribution of the researchers (Delone\& McLean, 2003; Vallerand, 1997; Bandura, 2001;Davis, 1989; Hofstede, Hofstede \& Minkov, 2010).

With the increased use of mobile phones and other mobile like devices, the demand of integrating m-learning in the curriculum of Higher Education has increased. Nevertheless, it is necessary to explore if the integration of m-learning within the curriculum of Higher Education will have a positive effect on the faculty members and students' academic performance in the educational context of Pakistan. In this way, it is argued by Iqbal and Bhatti (2017) that, "M-learning success in the educational context depends on the perceptions and participation of the stakeholders which include students, faculty, university management and support staff. Any m-learning initiative cannot be successful unless it is welcomed by end users, that is, students, therefore it is important to determine the factors affecting students' intentions to adopt m-learning" (p. 2).

As students and educators, having mobile devices, can have access to medium of communication, host of affordances, real-time information, and a large number of other useful functions, it also carries the chances to cheat, distraction, and deviation from the assigned tasks. Hence, an evidence-based study is a prerequisite to figure out the ways and strategies to enhance the quality of learning within the academic classrooms in Pakistan. The present study is intended to transform the educational process by converting it into effective and attractive for both the students and the educators. The determinants mentioned in the theories including avoid uncertainty, usefulness and easy to use, information and system quality, SCT self-efficacy, and MM's Enjoyment were collectively evaluated to observe the impact of mobile devices access and faculty performance (based on gender difference) of business schools in Pakistan.

\section{Hypotheses}

$\mathbf{H}_{1}$ : Female faculty performance of business schools does not differ to the male faculty performance of business schools in Pakistan 


\section{Review of Literature}

The term Mobile Learning (or m-learning), refers to a "social rather than technical phenomenon of people on the move, constructing spontaneous learning contexts and advancing through everyday life by negotiating knowledge and meanings through interactions with settings, people and technology" (Yu, Niemi, \& Mason, 2019, p. 145). Ciampa (2014) argues that mobility of learners is the major focus in m-learning so learners can have interaction with their peers and instructors using portable technologies. Furthermore, the m-learning supports the learning which accommodates reflection on how society and institutions supports such technologies. Within the educational system, the m-learning assists the learners to have a continuous access to the learning process by using mobile or mobile like devices such as laptop, tablet, IPad etc. (Bano, Zowghi, Kearney, Schuck, \& Aubusson, 2018). Hence, learners with the exposure of m-learning can have the opportunity to keep engaged in learning from anywhere.

\section{Academic Performance of Students and Mobile Learning}

Mobile devices usually contain features and applications designed for learners to enhance their learning. Conducted study on one of the mobile applications designed for learners known as Martha Speaks Dog Party (MSDP), Neumann (2016) found that the application is a great source to help students in increasing their vocabulary. The findings of the study reveal that students can increase their vocabulary as 31 per cent faster than without using MSDP within two weeks. The findings of the study conducted by Deaton, Herron, and Deaton (2018) to analyse the importance of the m-learning inclusion in classrooms, reveal that students feel motivated with the implementation of the mobile learning both inside and outside of their classrooms. Furthermore, they have more opportunities to keep themselves engaged in the assigned learning tasks with the help of mobile applications. Similarly, the results found by the study conducted by Mehdipour \& Zerehkafi (2013) show that educators can offer their students modern ways, with the implementation of the mobile learning, to support the learning process.

According to Uzunboylu, Cavus \& Ercag (2009), the increased accessibility of the mobile phones has made it easy for students to grasp knowledge. It has also opened the door for teachers to keep their students motivated and engaged in various learning activities. Conducting study on the benefits of mobile learning, Uzunboylu, Cavus, \& Ercag (2009)

found that having the innovative computing facilities, mobile phone enable the students to get updated lessons and instructions on time. The study conducted by Kim, Mims, \& Holmes, (2006) to determine a abundant of mobile learning standpoints of students enrolled in university for accounting courses. The study aimed to determine the difference between the time spent by the accounting students to learning and their perspectives regarding the mobile learning.

Kruskal Wallis test and Mann Whitney $U$ test were used to answer these questions. The survey consisted of $51 \%$ of females and $48 \%$ of males mostly falling into the category of $22-23$ age limit (58\%) and 24-25 age limit (27\%). Rest of the target audience was below 
22 years old and above 25 years old. There were around $77 \%$ of survey participants who were using mobile phone for educational purposes and accounting lessons. Around 51 out of 343 participants utilized mobile phones less than an hour for conversation, 38 participants used it for 1-3 hours on internet, 45 participants enjoyed playing games for less than an hour and 46 of them learned accounting lessons on mobile phones for less than an hour. The findings of research showed that most of them agreed that reliable service of mobile learning makes it effective and a good alternative for those who are employed. Mann Whitney $U$ test showed that there are significant differences between using mobile phones for educational purposes and learning. The probability of participants having knowledge of using mobile phone is 0.019 . And they are interested in carrying out learning activities of accounting lessons by using mobile phones is 0.034 which is less than 0.05 and is highly significant. Not only this, the information can be navigated easily making learning material accessible agreed by 265 out of 343 participants(Crompton \& Burke, 2018). The results reveal that students feel discourage for the use of mobile phones for educational purpose because of the unavailability of technical support available within the premises of universities and thus they tend to spend less time using mobile phones for their learning. Nevertheless, a large number of students display positive attitude for learning via mobile phones due to convenience and accessibility being provided to the students (Almasri, 2016).

A study conducted by Sarrab, Elgamel \& Aldabbas (2012) investigated the mobile learning in terms of barriers, benefits and applications. The purpose was to introduce a new model for Mobile Learning Success based on McLean and DeLone Information System Success Model and Technology Acceptance Model (TAM) (DeLone \& McLean, 1992). The findings of the study revealed that the integration of "Wireless Communication Technology" (also known as mobile learning) into the educational setting for the sake of learning to take place regardless of the user's location. Deegan and Rothwell (2010) discuss that with sufficient supply of ubiquitous environment of learning, certain characteristics attached with mobile learning clarifies the picture presented by previous observers.

\section{Adoption Intention and Mobile Learning}

According to Liu, Li, and Carlsson (2010), adaptation method is to meet the needs of learners where mobile learning facilitate the learners regarding learning time, time flexibility, assimilated instructional context, collaborative sessions to acquire knowledge, and situational instructional activities. In the light of the study conducted by KukulskaHulme (2009), it is right to state that hand-held devices (mobile of mobile like devices) are more beneficial for technical fields including archaeology and environmental studies. Some of the significant benefits include the improved communication, accuracy in the recorded data, making use of timing. Kukulska-Hulme (2009) and Kukulska-Hulme \& Traxler (2005) point out that in the project "MyArt Space" students were supposed to, having a trip to museum, share audio recordings, videos, notes captured. The trip led the students to collaborative learning in which the group discussions developed their interest and increased their motivation to explore the targeted museum energetically. Throughout 
the trip, mobile phones (as well as other mobile like devices) played the role of bridge to increase their interest and motivation.

While conducting a study, Kenny, Van Neste-Kenny, Park, Burton \& Meiers (2009) designed a research project to include libraries in order to deliver, in course management system, learning resources. The course management system was envisioned as " $\mathrm{m}$-course management system" by the researchers in which mobile learners was given due importance. It was found that the m-course management system was successfully able to address the issue associated with persistence and retention of students enrolled in the higher education. Nevertheless, the issue associated with the digital divide seems to make it difficult to integrate the mobile learning in the higher education. According to Kenny, Van Neste-Kenny, Park, Burton \& Meiers (2009), the healthcare system in the modern era requires the healthcare challenges to be managed at fast pace. From this perspective, nursing students require to be taught using the advanced technologies "The resulting learning environment exist both onsite as digital interactive content and online on web" (Hsu, Ke \& Yang, 2006, p. 21). By stating this viewpoints, the authors tend to argue that the integration of the mobile learning is encouraged by the current evolution of information on its fast track, as it creates extra channels for communication. According to Hsu, Ke, and Yang, (2006), consistency and uniformity in learning has made the mobile learning adaptable. Therefore, a large number of mobile applications have been designed to assist the learners to increase their learning.

\section{Methodology}

Neuman (2013) explains that two approaches, within the paradigm of quantitative research study, are used to handle the gathered data including the inferential and descriptive analysis. This study uses both of the approaches to control the data gathered from the selected participants. By using the descriptive analysis, the study describes the participating faculty members in terms of their different genders, the semester they are enrolled in currently, the business program they are enrolled in, and so on while by using the inferential analysis, it tends to justify the hypothesised statement. The purpose to us the descriptive analysis is to present the characteristics' description of the sample size. It also attempts to reconnoitre the performance of the participating faculty members with the assistance of the implementation of the inferential analysis approach. Since this study aims to transform the educational process by making it effective and attractive to the students by suggesting the inclusion of mobile learning, portable devices such as mobile phones were required to create the collaborative activities within the classrooms under the supervision of the faculty members. Furthermore, the inferential analysis approach was also used to explore the internet-oriented lectures delivered by the faculty members to measure their competency levels in terms of delivering the comprehensive lectures.

This study used the survey method to collect data from the participating faculty members to measure the influence of the inclusion of mobile learning on faculty members' performance based on their different genders. To conduct the survey, an adopted 
questionnaire (from the study conducted by Gan \& Balakrishnan in 2018) was used to measure the factors associated with the adoption intention (Appendix A). Gan \& Balakrishnan (2018) aimed to developed the questionnaire was to explore the factors associated with the adoption and use of mobile technology to increase the interaction between students and lecturers. Nevertheless, in order to measure the performance of the faculty members with the inclusion of mobile learning, Google class was introduced to the faculty members to conduct this experiment.

\section{Google Classrooms}

The term "Google Classroom" (GC) refers to a free service available in Google account. Any individual having google account can use it at any time and any place. GC makes the workload of both the faculty members and the students easy. According to Hockenson (2015), "Classroom saves time and paper, and makes it easy to create classes, distribute assignments, communicate, and stay organized" (p.n.d).

The present study targeted population includes faculty members currently serving in Business Schools in Karachi. It was mandatory for the faculty members to be teaching any program offered by the selected Business Schools in Karachi such as BBA, MBA, MPhil/Ms, and PhD. In this way, ten faculty members were invited, for the training in which they were trained how to integrate Google Class into their regular classes, from each of the selected business school (total of 22) in Karachi. The selection of business school was based on purposive sampling, as it was mandatory for the Business Schools to be accredited by "National Business Education Accreditation Council" (NBEAC). On the other hand, the quota sampling technique was used to invite the faculty members from each of the selected school. Subsequent to the selection of the business schools, faculty members, and their training, the faculty members were requested to implement the google class for one complete semester.

The gathered data was analysed by employing Paired Samples Test using Statistical Package to compare the variable "academic performance of business students" in both conditions such as 1) before business students' exposure to mobile learning and 2) after business students' exposure to mobile learning.

\section{Results and Findings}

Table 1 reveals that the highest age group of the faculty members was $50+(59.1$ per cent). The gender-based classification of the participating faculty members was not equal as the female faculty members were 63.2 per cent while the male faculty members were 36.8 per cent. The number of faculty members currently holding MBA degree was the highest one (46.8 per cent) possessing the Smart Phone ( 84.5 per cent) stating Wi-Fi as their preferred internet device ( 92.7 per cent). It is noteworthy that all of the selected business 
schools provided the Wi-Fi connection with open access within the premises of the respective universities. Similarly, mobile phone was the preferred device used by faculty members to deliver lectures in business schools, as 65.5 per cent faculty members declared that they used mobile phones for teaching purpose.

Table - 1

Participating faculty members' descriptive analysis

\begin{tabular}{|c|c|c|}
\hline \multicolumn{3}{|l|}{ Age } \\
\hline & Frequency & Percent \\
\hline $31-40$ & 30 & 13.6 \\
\hline $41-50$ & 60 & 27.3 \\
\hline $50+$ & 130 & 59.1 \\
\hline \multicolumn{3}{|l|}{ Gender } \\
\hline Female & 139 & 63.2 \\
\hline Male & 81 & 36.8 \\
\hline \multicolumn{3}{|l|}{ Educational level } \\
\hline MBA & 103 & 46.8 \\
\hline MPhil & 35 & 15.9 \\
\hline $\mathrm{PhD}$ & 82 & 37.3 \\
\hline \multicolumn{3}{|c|}{ Owned technological devices } \\
\hline Smart Phone & 186 & 84.5 \\
\hline laptop & 21 & 9.5 \\
\hline other & 13 & 5.9 \\
\hline \multicolumn{3}{|l|}{ Preferred device } \\
\hline Cellular network & 12 & 5.5 \\
\hline Wifi & 204 & 92.7 \\
\hline Wired Ethernet connection & 4 & 1.8 \\
\hline \multicolumn{3}{|l|}{ Wi-fi connection institute } \\
\hline Yes & 220 & 100.0 \\
\hline \multicolumn{3}{|c|}{ Preferred device for teaching } \\
\hline Smartphone & 144 & 65.5 \\
\hline laptop & 47 & 21.4 \\
\hline $\mathrm{Tab}$ & 19 & 8.6 \\
\hline Other & 10 & 4.5 \\
\hline Total & 220 & 100.0 \\
\hline
\end{tabular}

Table 2 reveals the descriptive statistics of received responses of faculty members. 
Table -2

Descriptive statistics of faculty members' responses

\begin{tabular}{|c|c|c|c|c|c|c|c|c|c|c|}
\hline \multicolumn{11}{|c|}{ Descriptive Statistics } \\
\hline & Range & $\begin{array}{l}\text { Mini- } \\
\text { mum }\end{array}$ & $\begin{array}{l}\text { Maxi- } \\
\text { mum }\end{array}$ & \multicolumn{2}{|c|}{ Mean } & Std. Dev & \multicolumn{2}{|c|}{ Skewness } & \multicolumn{2}{|c|}{ Kurtosis } \\
\hline & Statistic & Statistic & Statistic & Statistic & SE & Statistic & Statistic & SE & Statistic & SE \\
\hline $\begin{array}{l}\text { Adoption } \\
\text { Intention }\end{array}$ & 4.00 & 1.00 & 5.00 & 2.439 & .101 & 1.511 & .613 & .164 & -1.218 & .327 \\
\hline $\begin{array}{l}\text { System } \\
\text { Quality }\end{array}$ & 4.00 & 1.00 & 5.00 & 3.103 & .095 & 1.416 & .112 & .164 & -1.638 & .327 \\
\hline $\begin{array}{l}\text { Information } \\
\text { Quality }\end{array}$ & 3.60 & 1.40 & 5.00 & 3.620 & .082 & 1.229 & -.331 & .164 & -1.499 & .327 \\
\hline $\begin{array}{l}\text { Perceived } \\
\text { Usefulness }\end{array}$ & 4.00 & 1.00 & 5.00 & 3.830 & .069 & 1.037 & -.941 & .164 & .250 & .327 \\
\hline $\begin{array}{l}\text { Perceived } \\
\text { Ease of Use }\end{array}$ & 4.00 & 1.00 & 5.00 & 4.011 & .062 & .925 & -1.149 & .164 & 1.878 & .327 \\
\hline Enjoyment & 4.00 & 1.00 & 5.00 & 4.048 & .061 & .906 & -1.323 & .164 & 2.405 & .327 \\
\hline $\begin{array}{l}\text { Self- } \\
\text { Efficacy }\end{array}$ & 3.60 & 1.40 & 5.00 & 4.090 & .061 & .907 & -.931 & .164 & .727 & .327 \\
\hline $\begin{array}{l}\text { Uncertainty } \\
\text { Avoidance }\end{array}$ & 4.00 & 1.00 & 5.00 & 4.028 & .064 & .949 & -1.182 & .164 & 1.614 & .327 \\
\hline
\end{tabular}

Table 3 indicates that the items used for each of the constructs have internal consistency and thus they are reliable to measure the respective constructs.

Table -3

Reliability test

\begin{tabular}{|l|c|c|c|c|c|}
\hline & \multicolumn{2}{|c|}{ Pilot Test } & \multicolumn{2}{c|}{ Final Test } & \\
\hline \multicolumn{1}{|c|}{ Constructs } & $\begin{array}{c}\text { Cronbach's } \\
\text { Alpha }\end{array}$ & $\begin{array}{c}\text { N of } \\
\text { Items }\end{array}$ & $\begin{array}{c}\text { Cronbach's } \\
\text { Alpha }\end{array}$ & $\begin{array}{c}\text { N of } \\
\text { Items }\end{array}$ & $\begin{array}{c}\text { Items } \\
\text { Deleted }\end{array}$ \\
\hline Adoption Intention & .860 & 5 & .759 & 5 & - \\
\hline System Quality & .750 & 5 & .842 & 5 & - \\
\hline Information Quality & 0.698 & 5 & .752 & 5 & - \\
\hline Perceived Usefulness & 0.738 & 5 & .892 & 5 & - \\
\hline Perceived Ease of Use & 0.838 & 5 & .799 & 5 & - \\
\hline Enjoyment & 0.648 & 5 & .739 & 5 & - \\
\hline Self-Efficacy & 0.795 & 5 & .847 & 5 & - \\
\hline Uncertainty Avoidance & 0.598 & 5 & .692 & 5 & - \\
\hline
\end{tabular}

Table 4 is used to justify the hypothesis of the present study, which indicates no difference between the male and female faculty performance of business schools in Pakistan. From this perspective, this study fails to reject the null hypothesis "Female faculty performance of business schools differs to the male faculty performance of business schools in Pakistan." 
Table -4

Independent samples test

\begin{tabular}{|l|l|c|c|c|c|c|}
\hline \multicolumn{2}{|c|}{} & \multicolumn{2}{|c|}{$\begin{array}{c}\text { Levene's Test } \\
\text { for Equality of } \\
\text { Variances }\end{array}$} & \multicolumn{2}{|c|}{ t-test for Equality of Means } \\
\cline { 3 - 7 } \multicolumn{2}{|c|}{} & F & Sig. & t & df & Sig. (2-tailed) \\
\hline \multirow{5}{*}{$\begin{array}{l}\text { Faculty } \\
\text { Performance }\end{array}$} & $\begin{array}{l}\text { Equal variances } \\
\text { assumed }\end{array}$ & 0.514 & 0.474 & -1.478 & 218 & 0.141 \\
\cline { 2 - 7 } & $\begin{array}{l}\text { Equal variances } \\
\text { not assumed }\end{array}$ & & & -1.493 & 172.776 & 0.137 \\
\cline { 2 - 7 } & & $\mathrm{N}$ & Mean & $\begin{array}{c}\text { Std. } \\
\text { Deviation }\end{array}$ & \multicolumn{2}{|c|}{ Std. Error Mean } \\
\cline { 2 - 7 } & Female & 139 & 3.5856 & 0.81314 & \multicolumn{2}{|c|}{0.06897} \\
\cline { 2 - 7 } & Male & 81 & 3.7512 & 0.78214 & \multicolumn{2}{c|}{0.0869} \\
\hline
\end{tabular}

\section{Discussion}

Subsequent to reviewing the related literature, it is clear that the advancement in the mobile technology had made its use increased significantly in several fields such as entertainment, banking, tourism, economy, library, and education. Such advancement has also urged the educationists worldwide to focus on its use in the educational industry. For instance, Bano et al., (2018) found that learning with mobile phones makes the learners of today's technological advanced era more comfortable and thus helps them to increase their learning. The shift of electronic era to mobile services has started following the paradigm "anytime, anywhere computing." Similarly, Neumann (2016) examines one of the applications named as "Martha Speaks Dog Party" (MSDP), which has been designed in the context of vocabulary learning. The results of the study show that the participating students, aged between "three and seven years", improved their vocabulary by 31 per cent within the period of merely two weeks. Deaton, Herron, and Deaton (2018) find that students feel themselves to be more motivated with the application of mobile learning inside the classrooms. Furthermore, they are more intended to keep themselves engaged in the learning contents, which makes them self-study outside the classrooms and also decease their learning anxiety. Mehdipour \& Zerehkafi (2013) point out that "Mobile learning, or m-Learning, offers modern ways to support learning process through mobile devices, such as handheld and tablet computers, MP3 players, smart phones and mobile phones" (p. 93). The findings of the study second the reviewed literature figuring out by suggesting its use in the educational industry.

The findings of the present study are not dissimilar to the studies reviewed. For example, Lehner, Nosekabel, and Lehmann (2003) found that learning with the help of mobile phones makes the learners of today's technological advanced era more comfortable and thus helps them to increase their learning. The shift of electronic era to mobile services has started following the paradigm "anytime, anywhere computing." Furthermore, the found results of the study are also similar to the studies conducted by Sarrab, Elgamel, \& Aldabbas (2012), Kutluk \& Gulmez (2014), Kim, Mims \& Holmes, (2006) and Uzunboylu, Cavus, \& Ercag (2009) in which the researcher concluded that wireless 
communication technology (mobile phones) could be integrated in students learning regardless of the locations of users. Nevertheless, the present study also supports the results of the conducted by Kutluka \& Gulmez (2014) describing that students feel discouraged when universities do not provide with the technical support.

\section{Conclusions and Recommendations}

Subsequent to the reviewed literature as well as the findings of the present study, it would be perfect to conclude that the inclusion of mobile learning within the educational setting will support the learners a continuous access to the learning process. Having the technology oriented classes, from this perspective, students have the opportunity to learn anything from anywhere. Nevertheless, while comparing the achieved scores of business faculty members based on their different genders (male and female), no difference was found. Sit shows that along with the students' academic achievement faculty members also tend to increase their performance equally (regardless of their different gender) with the inclusion of mobile learning in their classes. This is because mobile phones usually contain features and applications (such as google class) that help learners engage with the provided resources. Mobile phones "known as smart phones" with the advanced computing facilities empower the users (both students and faculty members regardless of their gender) to receive information related to their lessons, emails from instructors, sharing multimedia files, exchanging lecture notes.

\section{References}

Allen, R. (2011). Can Mobile Devices Transform Education? .ASCD, vol.01, pp.15-20.

Ally, M. \& Prieto-Blázquez, J. (2014). What is the Future of Mobile Learning in Education? International Journal of Educational Technology in Higher Education, vol.11:1, pp.142-151.

Almasri, A. K. M. (2016). Proposed M-Learning Model Based on Two Models (Technology Acceptance Model and DeLone and McLean IS success Model). International Journal of Computer Applications, vol.142:4.

Bandura, A. (2001). Social Cognitive Theory: An Agentic Perspective. Annual Review of Psychology, vol.52, pp.1-26.

Bano, M., Zowghi, D., Kearney, M., Schuck, S. \& Aubusson, P. (2018). Mobile Learning for Science and Mathematics School Education: A Systematic Review of Empirical Evidence. Computers \& Education, vol.121, pp.30-58.

Beal, V. (2018). What is Mobile Learning (m-learning)? Webopedia Definition. Webopedia.com. Retrieved 1 May 2018, from https://www.webopedia.com/ TERM/M/mobile-learning-m-learning.html.

Ciampa, K. (2014). Learning in a Mobile Age: An Investigation of Student Motivation. Journal of Computer Assisted Learning, vol.30:1, pp.82-96. 
Clark, J. D. \& Ed, M. (2007). Learning and Teaching in the Mobile Learning Environment of the Twenty-First Century. Instructional Design Specialist Austin Community College, Austin, Texas, vol.19:1, pp.1-105.

Crompton, H. \& Burke, D. (2018). The Use of Mobile Learning in Higher Education: A Systematic Review. Computers \& Education, vol.123, pp.53-64.

Davis, F. (1989). Perceived Usefulness, Perceived Ease of Use and User Acceptance of Information Technology. MIS Quarterly, vol.13:3, pp.319-340.

Deaton, B., Herron, J. \& Deaton, C. C. (2018). Mobile Technology and Learning. In Handbook of Research on Human Development in the Digital Age (pp. 87-108). IGI Global.

Deegan, R. \& Rothwell, P. (2010). A Classification of M-Learning Applications from a Usability Perspective, Journal of the Research Center for Educational Technology, vol.6:1, pp.16-27.

DeLone, W. H. \& McLean, E. R. (1992). Information Systems Success: The Quest for the Dependent Variable. Information Systems Research, vol.3:1, pp.60-95.

Delone, W. H. \& McLean, E. R. (2003). The DeLone and McLean Model of Information Systems Success: A Ten-Year Update. Journal of Management Information Systems, vol.19:4, pp.9-30.

Gan, C. L. \& Balakrishnan, V. (2018). Mobile Technology in the Classroom: What Drives Student-Lecturer Interactions? International Journal of Human-Computer Interaction, vol.34:7, pp.666-679.

Hockenson, L. (2015). Google Classroom Updates with Calendar Integration, New Teacher Tools. Retrieved from https://thenextweb.com/google/2015/08/24/google -classroom-back-2-school/

Hofstede, G., Hofstede, G. J. \& Minkov, M. (2010). Cultures and Organizations: Software of the Mind: Intercultural Cooperation and its Importance for Survival. New York, USA: McGraw-Hill.

Hsu, T. Y., Ke, H. R. \& Yang, W. P. (2006). Knowledge-Based Mobile Learning Framework for Museums. The Electronic Library, vol.24:5, pp.635-648.

Iqbal, S. \& Bhatti, Z. A. (2017). What Drives M-Learning? An Empirical Investigation of University Student Perceptions in Pakistan. Higher Education Research \& Development, vol.36:4, pp.730-746.

Kenny, R. F., Van Neste-Kenny, J. M., Park, C. L., Burton, P. A. \& Meiers, J. (2009). Mobile Learning in Nursing Practice Education: Applying Koole's FRAME Model. Journal of Distance Education (Online), vol.23:3, pp.75-95. 
Kim, S. H., Mims, C. \& Holmes, K. P. (2006). An Introduction to Current Trends and Benefits of Mobile Wireless Technology Use in Higher Education. AACE Journal, vol.14:1, pp.77-100.

Kukulska-Hulme, A. \&Traxler, J. (2005). (Eds.). Mobile Learning: A Handbook for Educators and Trainers. London: Routledge.

Kukulska-Hulme, A. (2009). Will Mobile Learning Change Language Learning? $\operatorname{ReCALL}, \mathrm{vol} .21: 2, \mathrm{pp} .157-165$.

Laouris, Y. \& Eteokleous, N. (2005, October). We Need an Educationally Relevant Definition of Mobile Learning. In Proceedings of mLearn (Vol. 2005).

Lehner, F., Nösekabel, H. \& Lehmann, H. (2003). Wireless E-Learning and Communication Environment: Welcome at the University of Regensburg. EService, vol.2:3, pp.23-41.

Liu, Y., Li, H. \& Carlsson, C. (2010). Factors Driving the Adoption of M-Learning: An Empirical Study. Computers \& Education, vol.55:3, pp.1211-1219.

Mehdipour, Y. \& Zerehkafi, H. (2013). Mobile Learning for Education: Benefits and Challenges. International Journal of Computational Engineering Research, vol.3:6, pp.93-101.

Nassuora, A. B. (2012). Students Acceptance of Mobile Learning for Higher Education in Saudi Arabia. American Academic \& Scholarly Research Journal, vol.4:2, pp.24-30.

Neuman, W. L. (2013). Social Research Methods: Qualitative and Quantitative Approaches. Pearson Education.

Neumann, M. M. (2016). Young Children's Use of Touch Screen Tablets for Writing and Reading at Home: Relationships with Emergent Literacy. Computers \& Education, vol.97, pp.61-68.

Sarrab, M., Elgamel, L. \& Aldabbas, H. (2012). Mobile Learning (M-Learning) and Educational Environments. International Journal of Distributed and Parallel Systems, vol.3:4, p.31.

Uzunboylu, H., Cavus, N. \&Ercag, E. (2009). Using Mobile Learning to Increase Environmental Awareness. Computers \& Education, vol.52:2, pp.381-389.

Vallerand, R. J. (1997). Toward a hierarchical model of intrinsic and extrinsic motivation. In Advances in experimental social psychology (Vol. 29, pp. 271-360). Academic Press.

Yu, S., Niemi, H., \& Mason, J. (Eds.). (2019). Shaping Future Schools with Digital Technology: An International Handbook. Springer Nature. 


\section{APPENDIX A \\ Data Collection Instrument \\ Demographics}

\begin{tabular}{|c|c|c|}
\hline Age & Other & What do you prefer \\
\hline Gender & Preferred device to & to use for your learning? \\
\hline Educational level & use internet & Smart Phone \\
\hline Owned Technological & Cellular network & Laptop \\
\hline devices: & WiFi & $\mathrm{Tab}$ \\
\hline $\begin{array}{l}\text { Smart Phone } \\
\text { Laptop }\end{array}$ & $\begin{array}{l}\text { - Wired } \\
\text { connection }\end{array}$ & Other \\
\hline Tab & $\begin{array}{l}6 . \quad \text { Does your institute } \\
\text { provide Wi-Fi connection? }\end{array}$ & \\
\hline
\end{tabular}

Constructs \& Items

\begin{tabular}{|c|c|c|c|c|c|c|c|}
\hline \begin{tabular}{|l|l} 
No \\
\end{tabular} & Codes & Constructs \& Items & 5 & 4 & $\underline{3}$ & & 1 \\
\hline \multicolumn{8}{|c|}{ Adoption Intention } \\
\hline 1 & AI1 & $\begin{array}{l}\text { I prefer to ask questions during lecture by typing and } \\
\text { sending the questions using mobile messaging } \\
\text { application to my lecturer mobile device. }\end{array}$ & & & & & \\
\hline 2 & AI2 & $\begin{array}{l}\text { I prefer to respond to my lecturer questions during } \\
\text { lecture by typing and sending the answers using } \\
\text { mobile messaging application to my lecturer mobile } \\
\text { device }\end{array}$ & & & & & \\
\hline 3 & $\mathrm{AI} 3$ & $\begin{array}{l}\text { My lecturer should allow and encourage us to send } \\
\text { or answer questions during lectures using mobile } \\
\text { messaging application. }\end{array}$ & & & & & \\
\hline 4 & AI4 & $\begin{array}{l}\text { My university/college should promote the use of } \\
\text { mobile technology to allow students and lecturers to } \\
\text { communicate during lectures. }\end{array}$ & & & & & \\
\hline 5 & AI5 & $\begin{array}{l}\text { Overall, I prefer to use mobile technology to } \\
\text { communicate with my lecturer during lecture } \\
\text { sessions. }\end{array}$ & & & & & \\
\hline \multicolumn{8}{|c|}{ System Quality } \\
\hline 6 & SQ1 & $\begin{array}{l}\text { I rarely encounter system errors when using mobile } \\
\text { devices/applications. }\end{array}$ & & & & & \\
\hline 7 & SQ2 & $\begin{array}{l}\text { It is easy to recover from errors encountered when } \\
\text { using mobile devices/applications. }\end{array}$ & & & & & \\
\hline 8 & SQ3 & $\begin{array}{l}\text { I find it easy to get mobile applications to do what I } \\
\text { want it to do. }\end{array}$ & & & & & \\
\hline 9 & SQ4 & $\begin{array}{l}\text { Mobile chat application(s) which I am using has } \\
\text { very good features. }\end{array}$ & & & & & \\
\hline
\end{tabular}




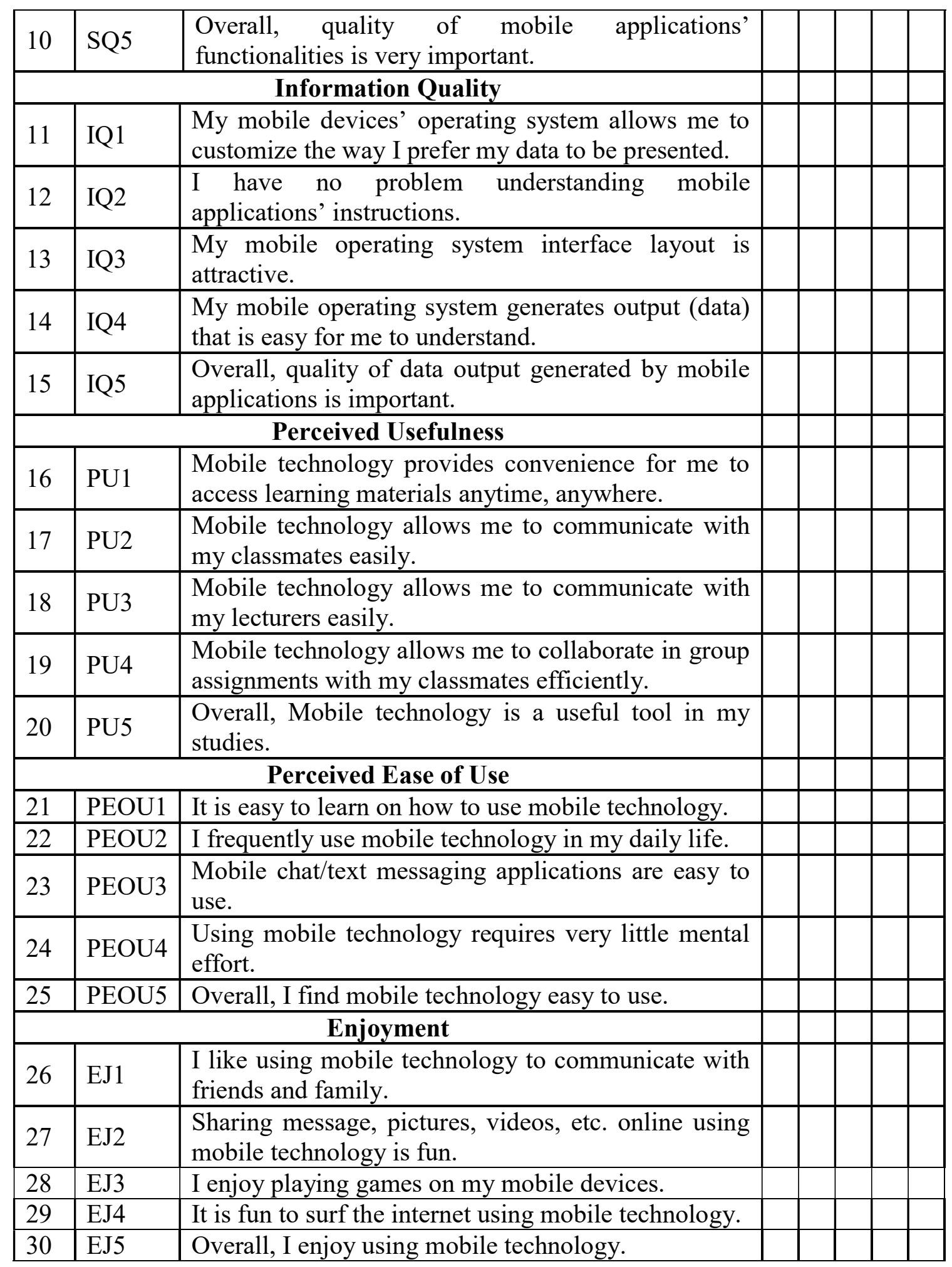




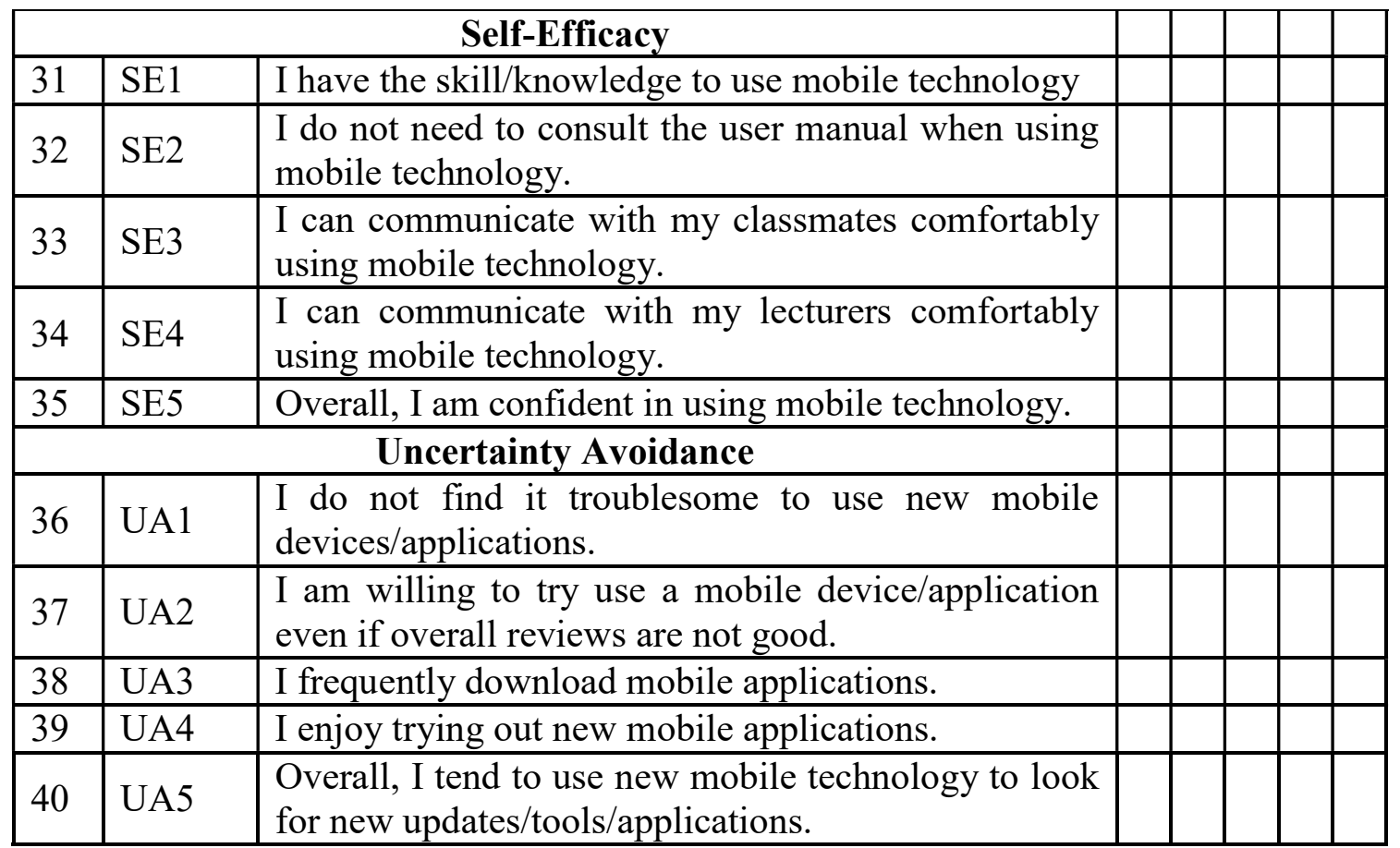

Gan and Balakrishnan constructed this instrument in 2017 to measure the drivers associated with adoption intention.

Salman Manzoor is Research Scholar in the Department of Commerce, University of Karachi, Karachi, Pakistan.

Samiullah Sarwar is Lecturer in the Department of Education, University of Loralai.

Dr. Muhammad Asim is Chairman and Associate Professor in the Karachi University Business School, University of Karachi, Karachi, Pakistan. 